\title{
21. On the Reverse Natural Remanent Magnetism of Basalt at Cape Kawajiri, Yamaguchi Prefecture
}

\author{
By Eizo Asami \\ Physical Institute, Faculty of Literature and Science, Yamaguchi University \\ (Comm. by M. Maturama, M.J.A., Feb. 12, 1954)
}

A few data ${ }^{123)^{3 / 4)}}$ of the reverse natural remanent magnetism of rocks have been published hitherto since the pioneer work was carried out by M. Matuyama in 1929. ${ }^{5}$. For the purpose of studying palaeomagnetism, the writer has measured the natural remanent magnetism of test specimens of basalts and sedimentary rocks from the Japan Sea side of Yamaguchi Prefecture (west Japan) by means of an astatic magnetometer since autumn, 1950. Of the basalts, some specimens from Cape Kawajiri have shown reverse natural remanent magnetization, while those from all the other places were found to be normally magnetized. The age of eruption of the basalts which form Cape Kawajiri is generally considered to be early Pleistocene from geological point of view. The following is the

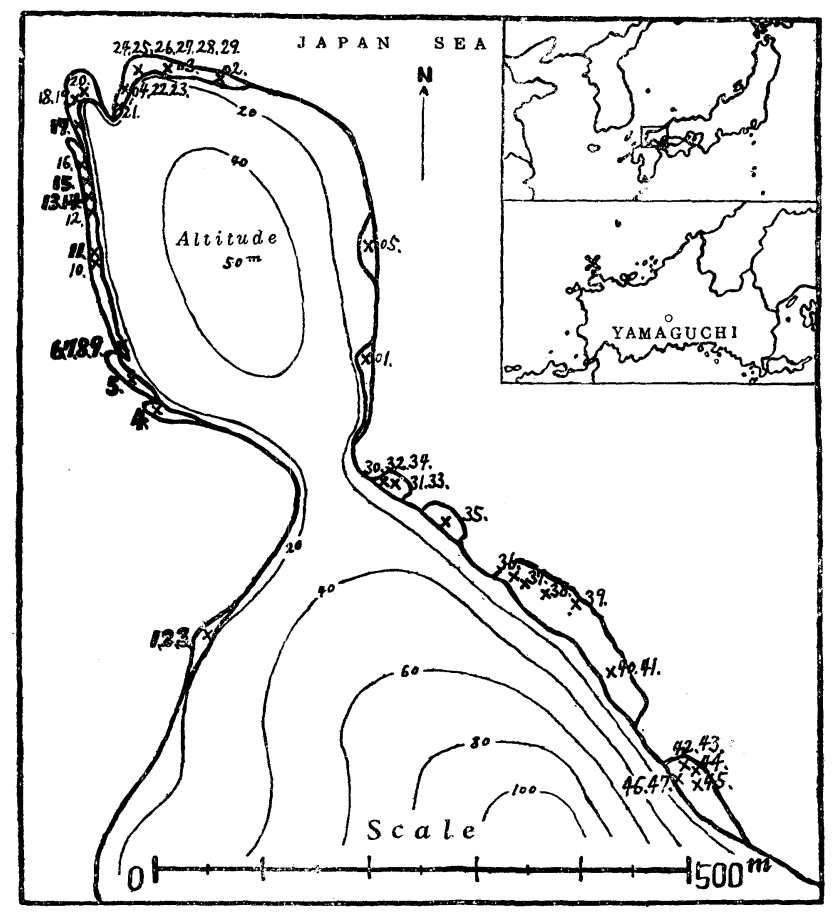

Fig. 1. Sampling places at Cape Kawajiri

Thicker numerals represent the specimens of normal magnetization and thinner ones represent those of reverse magnetization. 
result of measurement of the natural remanent magnetism of basalt specimens from Cape Kawajiri.

Fig. 1 is a map of Cape Kawajiri, which seems to have been formed with the basalt of the same eruption. The marks of cross $(x)$ represent sampling places at the sea-shore, where the solid block of lava flow is found exposed. The inner part of the cape is covered with ordinary soil and test specimens could not be sampled from there. The numerals in Fig. 1 represent the specimen-numbers. The writer has measured carefully the directions and intensities of magnetization of 52 specimens and obtained the following results.

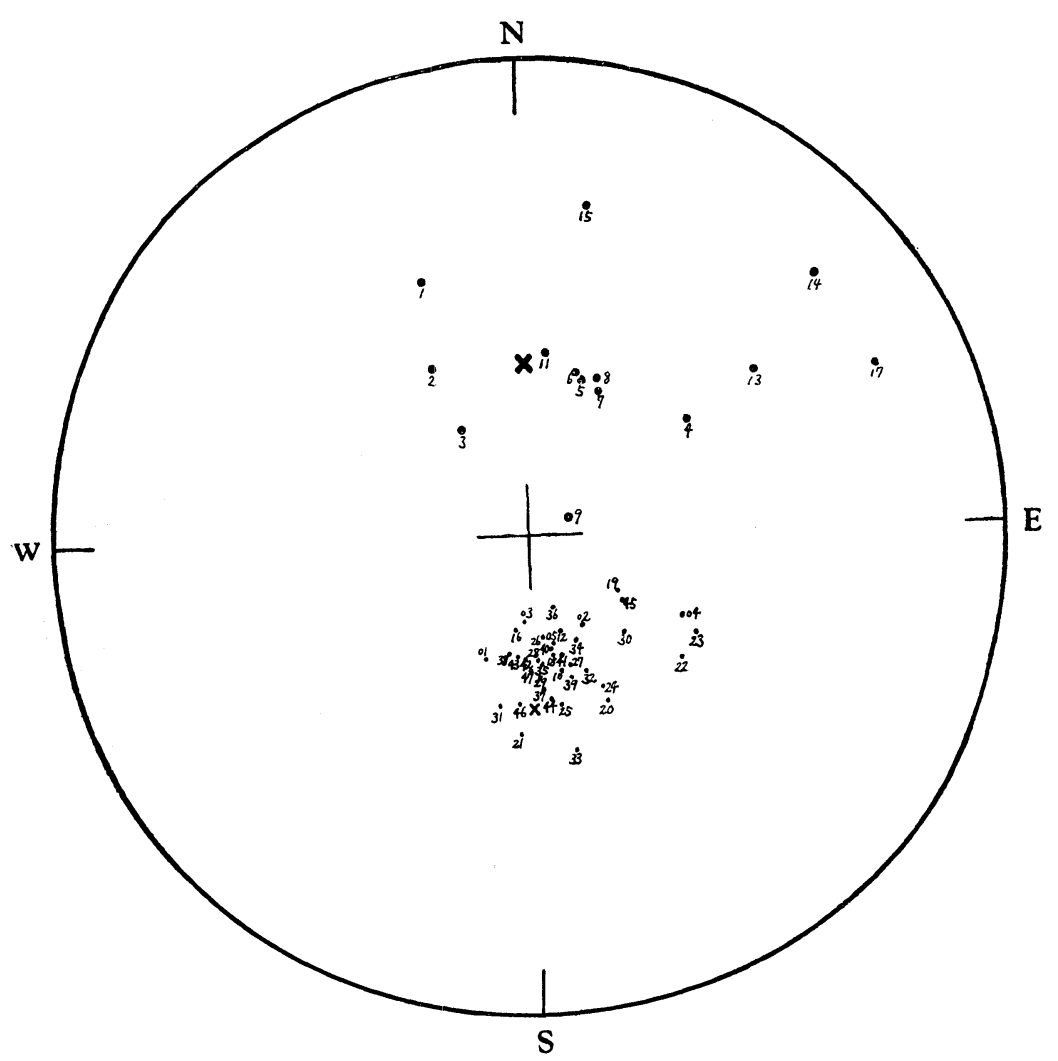

Fig. 2. Directions of magnetization of basalts from Cape Kawajiri

The north pointing directions of magnetization of these specimens are plotted in Fig. 2 by stereographic projection to Wulff's net. In Fig. 2, the thicker points represent the lower hemisphere and the thinner, the upper. The thicker mark of cross $(x)$ indicates the present geomagnetic north pole, whose declination is $\mathrm{N} 6^{\circ} \mathrm{W}$ from the geographical meridian and dip $+49^{\circ}$ downward from the horizontal plane. 
The intensities of magnetization of the specimens are shown in Table I with the unit of $10^{-3}$ e.m.u. $/ \mathrm{cm}^{3}$.

Table I

Intensities of magnetization of basalts from Cape Kawajiri

\begin{tabular}{|c|c|c|c|c|c|c|c|c|c|c|c|}
\hline $\begin{array}{l}\text { Speci- } \\
\text { men } \\
\text { Nos. }\end{array}$ & & $\begin{array}{c}\text { Inten- } \\
\text { sity }\end{array}$ & $\begin{array}{l}\text { Speci- } \\
\text { men } \\
\text { Nos. }\end{array}$ & & $\begin{array}{l}\text { Inten- } \\
\text { sity }\end{array}$ & $\begin{array}{c}\text { Speci- } \\
\text { men } \\
\text { Nos. }\end{array}$ & & $\begin{array}{l}\text { Inten- } \\
\text { sity }\end{array}$ & $\begin{array}{c}\text { Speci- } \\
\text { men } \\
\text { Nos. }\end{array}$ & & $\begin{array}{c}\text { Inten- } \\
\text { sity }\end{array}$ \\
\hline 1 & $\mathrm{~N}$ & 17.0 & 14 & $\mathrm{~N}$ & 0.6 & 26 & $\mathrm{R}$ & 4.3 & 35 & $\mathrm{R}$ & 1.0 \\
\hline 2 & , & 5.8 & 15 & ,, & 0.8 & 27 & , & 2.6 & 36 & , & 9.7 \\
\hline 3 & , , & 15.6 & 16 & $\mathrm{R}$ & 2.5 & 28 & , & 3.1 & 37 & ,, & 0.5 \\
\hline 4 & , , & 5.7 & 17 & $\mathrm{~N}$ & 6.2 & 29 & , , & 15.1 & 38 & , & 3.2 \\
\hline 5 & ,, & 7.4 & 18 & $\mathrm{R}$ & 1.8 & 03 & , , & 2.7 & 39 & , & 0.6 \\
\hline 6 & , & 32.6 & 19 & , & 4.5 & 02 & , & 3.1 & 40 & , & 0.6 \\
\hline 7 & , & 11.2 & 20 & , & 3.4 & 05 & , , & 1.3 & 41 & , , & 0.7 \\
\hline 8 & , , & 10.6 & 21 & , & 1.0 & 01 & , & 2.2 & 42 & , & 3.4 \\
\hline 9 & , & 0.8 & 04 & , & 1.7 & 30 & , , & 0.7 & 43 & ," & 4.3 \\
\hline 10 & $\mathrm{R}$ & 1.2 & 22 & , & 4.1 & 31 & , & 0.6 & 44 & , & 0.9 \\
\hline 11 & $\mathrm{~N}$ & 26.3 & 23 & , & 0.9 & 32 & , , & 0.6 & 45 & ,, & 0.7 \\
\hline 12 & $\mathrm{R}$ & 2.5 & 24 & , & 4.0 & 33 & , , & 0.6 & 46 & ,, & 0.6 \\
\hline 13 & $\mathrm{~N}$ & 0.5 & 25 & , & 5.4 & 34 & , & 1.1 & 47 & , & 1.2 \\
\hline
\end{tabular}

By comparing Fig. 1 with Fig. 2, it can be easily noticed about the directions that the specimens from No. 18 to No. 47 from the spit and east-side of the cape show the reverse magnetization without exception while those from No. 1 to No. 9 from west-side show the normal similarly without exception. In the part between No. 10 and No. 17, the specimens of normal and reverse magnetization are found intermixed in spite of the same eruption. The directions of magnetization of those 38 reverse specimens, as will be seen from Fig. 2, converge finely to the direction nearly opposite to the present geomagnetic field and the average deviation is $\mathrm{S} 13^{\circ} \mathrm{E}$ from geomagnetic south and dip $-56^{\circ}$ from the horizon. Those of the normal specimens diverge far wider from each other than those of the reverse specimens.

As we can see from Table I, the intensity of magnetization of these specimens at Cape Kawajiri is not uniform, while at all the other places it is fairly uniform. Roughly speaking, the average value of the intensity of the normal specimens is greater than that of the intensity of the reverse ones.

It is to be noticed that the normal and reverse basalts are found mostly in separate parts and that although the intensity is generally larger for normal points, it is much smaller at the points near and in the part caught between reverse points. It is the writer's opinion that these facts may have a significant meaning for the 
study of palaeomagnetism.

In conclusion, the writer wishes to express his heartiest thanks to Dr. M. Matuyama, President of Yamaguchi University, for his kind direction throughout this research. He is also much indebted to Mr. H. Domen, his assistant, for his help in sampling the specimens from the field and carrying on the whole work in the laboratory.

\section{References}

1) F. G. Bruckshaw and E. I. Robertson: Mon. Not. Roy. Astro. Soc., Geophys. Suppl., 5, 308 (1949).

2) N. Kumagai, N. Kawai, and T. Nagata: Jour. Geomag. Geoelect., 2, 61 (1950). N. Kawai : Jour. Geophys. Res., 56, 73 (1951).

3) J. Hospers : Nature, 168, 1111 (1951).

4) A. Roche : C. R. Acad. Sci., 233, 1132 (1951).

5) M. Matuyama: Proc. Imp. Acad., 5, 203 (1929). M. Matuyama: Proc. 4 th Pacific Sci. Congr., Java, 567 (1929). 